\title{
Effect of Therapy by Using Advocate Spot-On Combination (Imidacloprid 10\% and Moxidectin 2.5\%) on Subcutaneous Dirofilariosis in Dogs
}

\author{
Radmila Dobešová Paran and Vlasta Svobodová \\ Department of Parasitology, University of Veterinary and Pharmaceutical Sciences Brno, Palackého 1-3, 61242 Brno, Czech Republic \\ Correspondence should be addressed to Radmila Dobešová Paran, dobesova.radmila@seznam.cz \\ Received 15 November 2010; Revised 18 February 2011; Accepted 2 April 2011 \\ Academic Editor: Sven Poppert \\ Copyright ( $) 2011$ R. D. Paran and V. Svobodová. This is an open access article distributed under the Creative Commons \\ Attribution License, which permits unrestricted use, distribution, and reproduction in any medium, provided the original work is \\ properly cited.
}

\begin{abstract}
Dirofilaria (Nochtiella) repens is a filarioid parasite that causes subcutaneous dirofilariosis in dogs. Adults, while localized in subcutaneous tissues, lay embryos (microfilariae ( $\mathrm{mf})$ ) into the blood stream of dogs, which constitute a reservoir for infection of other definitive or accidental hosts as humans. This study was carried out to assess the efficacy of spot-on combination of imidacloprid and moxidectin on microfilariaemia in naturally infected dogs. A group of 11 dogs was monthly examined for the presence of microfilariae in peripheral blood by modified Knott's test method. Treatment was administered monthly for 4 months. All dogs (i.e., 100\%) became negative for microfilariaemia throughout the study. These results confirm the effect of the combination of imidacloprid and moxidectin on D. (Nochtiella) repens.
\end{abstract}

\section{Introduction}

Dirofilaria (Nochtiella) repens is a filarioid nematode of genus Dirofilaria that belongs to family Onchocercidae of the order Spirurida. Adults are mainly found in subcutaneous tissues where they may cause different clinical signs, such as dermal swelling, subcutaneous nodules, or pruritus [1].

Embryos are released into the blood stream by gravid female parasites and are ingested by mosquitoes during the blood meal. Over 60 mosquito species belonging to genus Anopheles, Culex, and Aedes could serve as vectors and produce infective (L3) larvae [2, 3]. Development of L3 is a temperate-dependent process, and climatic changes in last years enable the spread of canine subcutaneous dirofilariosis (CSD) from tropic and subtropics regions to temperate zone countries [4] such as Czech Republic [5], Slovakia [6], Hungary [7], and Austria [8].

Together with the spread of endemic CSD, there is an increase in transmission of $D$. repens, even to humans. People serve as occasional hosts in which aberrant migration of the larvae can cause different clinical signs [9]. Location of worms in the body can vary; nodules are found in subcutaneous tissue [10], lungs [9,11] or conjunctival tissue [12].
Their importance in the case of differential diagnosis of human neoplasia is high, and several authors described human dirofilariosis as emerging disease $[9,11]$.

This implies that the management of CSD has high importance in the prevention of human infections by $D$. repens. Individual cases of CSD treatment were described $[1,13]$. Field study for elimination of $D$. repens microfilariae in dogs using combination of moxidectin and imidacloprid was described [14]. The study describes specific protocol for D. repens infection treatment in dogs by commercial spot-on product (Advocate, Bayer).

\section{Materials and Methods}

2.1. Animals and Treatment. A total of 11 dogs were included in this study during the monitoring of Dirofilaria spp. infection in the southeastern area of the Czech Republic through years 2009/2010. The group was composed of outdoor-living dogs of various breeds, age, and gender, which were tested positive for $D$. repens $\mathrm{mf}$.

$D$. repens $\mathrm{mf}$ positive dogs were diagnosed after first blood sampling (examination no. 1). Consequently, after a 
TABLE 1: The influence of Advocate on the presence of Dirofilaria repens microfilariae in the blood of tested dogs.

\begin{tabular}{|c|c|c|c|c|c|c|c|c|c|c|c|}
\hline \multirow{3}{*}{ Examination $^{\dagger}$} & \multicolumn{11}{|c|}{ Treatment $^{\dagger \dagger}$} \\
\hline & \multicolumn{11}{|c|}{ Number of microfilariae/mL blood } \\
\hline & - & - & - & - & - & - & - & - & - & - & - \\
\hline 1 & 175 & 29 & 265 & 135 & 2830 & 187 & 2950 & 215 & 580 & 725 & 246 \\
\hline 2 & $\begin{array}{c}\sqrt{ } \\
113\end{array}$ & $\begin{array}{c}\sqrt{ } \\
106\end{array}$ & $\begin{array}{c}\sqrt{ } \\
168\end{array}$ & $\begin{array}{c}\sqrt{ } \\
1838\end{array}$ & $\begin{array}{c}\sqrt{ } \\
2169\end{array}$ & $\begin{array}{c}\sqrt{ } \\
119\end{array}$ & $\begin{array}{c}\sqrt{ } \\
2105\end{array}$ & $\begin{array}{c}\sqrt{ } \\
184\end{array}$ & $\begin{array}{c}\sqrt{ } \\
412\end{array}$ & $\begin{array}{c}\sqrt{ } \\
633\end{array}$ & $\begin{array}{c}\sqrt{ } \\
730\end{array}$ \\
\hline 3 & $\sqrt{ }$ & $\sqrt{ }$ & $\sqrt{ }$ & $\sqrt{ }$ & $\sqrt{ }$ & $\sqrt{ }$ & $\sqrt{ }$ & $\sqrt{ }$ & $\sqrt{ }$ & $\sqrt{ }$ & $\sqrt{ }$ \\
\hline & 0 & 0 & 0 & 0 & 0 & 0 & 0 & 0 & 0 & 0 & 0 \\
\hline 4 & $\sqrt{ }$ & $\sqrt{ }$ & $\sqrt{ }$ & $\sqrt{ }$ & $\sqrt{ }$ & $\sqrt{ }$ & $\sqrt{ }$ & $\sqrt{ }$ & $\sqrt{ }$ & $\sqrt{ }$ & $\sqrt{ }$ \\
\hline 4 & 0 & 0 & 0 & 0 & 0 & 0 & 0 & 0 & 0 & 0 & 0 \\
\hline 5 & $\sqrt{ }$ & $\sqrt{ }$ & $\sqrt{ }$ & $\sqrt{ }$ & $\sqrt{ }$ & $\sqrt{ }$ & $\sqrt{ }$ & $\sqrt{ }$ & $\sqrt{ }$ & $\sqrt{ }$ & $\sqrt{ }$ \\
\hline 5 & 0 & 0 & 0 & 0 & 0 & 0 & 0 & 0 & 0 & 0 & 0 \\
\hline 6 & - & - & - & - & - & - & - & - & - & - & - \\
\hline & 0 & 0 & 0 & 0 & 0 & 0 & 0 & 0 & 0 & 0 & 0 \\
\hline 7 & - & - & - & - & - & - & - & - & - & - & - \\
\hline & 0 & 0 & 0 & 0 & 0 & 0 & 0 & 0 & 0 & 0 & 0 \\
\hline 8 & - & - & - & - & - & - & - & - & - & - & - \\
\hline 0 & 0 & 0 & 0 & 0 & 0 & 0 & 0 & 0 & 0 & 0 & 0 \\
\hline 0 & - & - & - & - & - & - & - & - & - & - & - \\
\hline$y$ & 0 & 0 & 0 & 0 & 0 & 0 & 0 & 0 & 0 & 0 & 0 \\
\hline 10 & - & - & - & - & - & - & - & - & - & - & - \\
\hline 10 & 0 & 0 & 0 & 0 & 0 & 0 & 0 & 0 & 0 & 0 & 0 \\
\hline & - & - & - & - & - & - & - & - & - & - & - \\
\hline 11 & 0 & 0 & 0 & 0 & 0 & 0 & 0 & 0 & 0 & 0 & 0 \\
\hline & Dog 1 & $\operatorname{Dog} 2$ & $\operatorname{Dog} 3$ & $\operatorname{Dog} 4$ & $\operatorname{Dog} 5$ & Dog 6 & $\operatorname{Dog} 7$ & Dog 8 & $\operatorname{Dog} 9$ & Dog 10 & Dog 11 \\
\hline
\end{tabular}

${ }^{\dagger}$ Examinations were performed monthly (in one month interval).

${ }^{\dagger \dagger}$ Treatment with Advocate, Bayer (imidacloprid at $10-25 \mathrm{mg} / \mathrm{kg}$ and moxidection at $2.5-6,5 \mathrm{mg} / \mathrm{kg}$ ) monthly for four months (-no treatment, $\sqrt{ }$ treatment).

second blood sampling, dogs were treated following manufacturer's instructions by combination of imidacloprid ( $\mathrm{min}$ imum dosage $10 \mathrm{mg} / \mathrm{kg}$, max. $25 \mathrm{mg} / \mathrm{kg}$ ) and moxidection (min. dosage 2.5, max. $6.25 \mathrm{mg} / \mathrm{kg}$ ) in spot-on (Advocate, Bayer). Treatment was given monthly for 4 consecutive months. After the end of treatment, blood sampling and $\mathrm{mf}$ examination continued for 6 months. In total, this clinical study lasted 11 months. According to the owners, no other drug was given 5 months before and through the entire study.

2.2. Sampling and Examination. Peripheral venous blood $(3 \mathrm{~mL})$ was collected every month from each dog (vena cephalica antebrachii) into tubes with EDTA and transported into the laboratory on cooler blocks at about $4-5^{\circ} \mathrm{C}$. Blood samples were examined by a modified Knott's test [7] for detection of circulating mf. After centrifugation, all the sediment was collected, $\mathrm{mf}$ checked by light microscope (10x magnification), and the number of $\mathrm{mf} / 1 \mathrm{~mL}$ of blood calculated.

Commercial kit (Leucognost-SP) was used for mf identification by histochemical staining of acid phosphatase activity [15].

\section{Results}

Before treatment all dogs included in the study were $\mathrm{mf}$ positive (examination no. 1) in the range of $29-2950 \mathrm{mf} / \mathrm{mL}$.
All dogs were found positive for $D$. repens circulating $\mathrm{mf}$. One month after first treatment, no dog was found microfilaemic and lasted negative until the end of the study, that is, 6 months after the last treatment (see Table 1).

\section{Discussion}

The aim of the clinical study was to assess the efficacy of imidacloprid and moxidectin combination (Advocate, Bayer) on microfilariaemia level under field conditions. Dirofilariosis caused by $D$. repens is considered to be an emerging zoonoses [9], and it is spreading from tropical and subtropical countries to temperate zone. The main source of human infection is infected mosquitoes which had a blood meal on Dirofilaria-positive animals, mainly dogs [16]. The prevalence of human dirofilariosis rapidly increased in the last decades, even in areas where the infection was not expected [16-19]. Humans serve as dead-end hosts, where usually the parasites do not develop to adult stage [20] though few cases of circulating $\mathrm{mf}$ have been reported in humans $[16,21]$.

The prepatency of $D$. repens infection lasts 6 to 9 months $[22,23]$. Six months of sampling and examination after treatment were carried out to verify both the microfilaricidal effect and the preventive efficacy of the treatment. One hundred percent of dogs lasted negative 6 months after last treatment. 
This study was carried out in Czech Republic, a country that is in a temperate zone, where the first autochthonous case of canine dirofilariosis was found in 2006 [5]. During the following years, $D$. repens infection spread rapidly in wider areas, particularly along the main rivers [24].

Dogs can serve as source of infection regardless of circulating $\mathrm{mf}$ amount. On the other hand, longevity of $D$. repens leads to accumulation of parasites over years, and it could increase microfilariaemia. Therapy and prevention of subcutaneous dirofilariosis in dogs minimize the frequency of $\mathrm{mf}$ in their blood and dramatically reduce the risk of transmission. Reduction of infection source for vector decreases the risk of transmission and the further spread in dog population. Simultaneously, it poses the only way to control and inhibit transmission to human. Thus, therapy of $D$. repens positive dogs is recommended.

Until now, information about therapy and prevention of $D$. repens infection in dogs has been sporadic, and only few studies have been carried out with a combination of injectable melarsomine and oral administration of macrocyclic lactones, though the actual efficacy was questionable because of the death of the patient $[1,22]$.

\section{Conclusions}

The results of this study showed that a combination of imidacloprid (10-25 mg/kg) and moxidectin $(2,5-6,25 \mathrm{mg} / \mathrm{kg})$ in spot-on formulation (Advocate, Bayer) was safe and $100 \%$ effective in clearing circulating $\mathrm{mf}$ from the blood of naturally infected dogs one month after a single treatment. The treatment was repeated monthly for 4 consecutive months, and dogs lasted negative both throughout the treatment and during the further 6 months of the study.

\section{Acknowledgments}

Special thanks belong to the Bayer Animal Health GmbH, Leverkusen, Germany that supported this study from the beginning. At the same time the authors would like to thank all the owners of dogs for their cooperation and patience during the eleven-month duration of the study.

\section{References}

[1] G. Baneth, Z. Volansky, Y. Anug et al., "Dirofilaria repens infection in a dog: diagnosis and treatment with melarsomine and doramectin," Veterinary Parasitology, vol. 105, no. 2, pp. 173-178, 2002.

[2] G. Cancrini and S. Gabrielli, "Vectors of Dirofilaria nematodes: biology, behaviour and host/parasite relationships," in Mappe Parassitologiche_Dirofilaria, C. Guiseppe, Ed., pp. 4958, Naples, Italy, 2007.

[3] R. C. Anderson, Nematode Parasites of Vertebrates, Their Development and Transmission, GABI Publishing, Wallingford, UK, 2th edition, 200.

[4] C. Genchi, L. Rinaldi, M. Mortarino, M. Genchi, and G. Cringoli, "Climate and Dirofilaria infection in Europe," Veterinary Parasitology, vol. 163, no. 4, pp. 286-292, 2009.

[5] Z. Svobodová, V. Svobodová, C. Genchi, and P. Forejtek, “The first report of authochthonous dirofilariosis in dogs in the
Czech Republic," Helminthologia, vol. 43, no. 4, pp. 242-245, 2006.

[6] M. Miterpáková, D. Antolová, Z. Hurníková, and P. Dubinský, "Dirofilariosis in Slovakia-a new endemic area in Central Europe," Helminthologia, vol. 45, no. 1, pp. 20-23, 2008.

[7] O. Jacsó, M. Mándoki, G. Majoros et al., "First autochthonous Dirofilaria immitis (Leidy, 1856) infection in a dog in Hungary," Helminthologia, vol. 46, no. 3, pp. 159-161, 2009.

[8] M. Löwenstein and E. Spallinger, "First autochthonous case of canine Dirofilaria (Nochtiella) repens infection in Austriaa case report," Wiener Tierarztliche Monatsschrift, vol. 96, no. 7-8, pp. 184-187, 2009.

[9] S. Pampiglione, F. Rivasi, G. Angeli et al., "Dirofilariasis due to Dirofilaria repens in Italy, an emergent zoonosis: report of 60 new cases," Histopathology, vol. 38, no. 4, pp. 344-354, 2001.

[10] L. H. Kramer, V. V. Kartashev, G. Grandi et al., "Human subcutaneous dirofilariasis, Russia," Emerging Infectious Diseases, vol. 13, no. 1, pp. 150-152, 2007.

[11] F. Simón, J. López-Belmonte, C. Marcos-Atxutegi, R. Morchón, and J. R. Martín-Pacho, "What is happening outside North America regarding human dirofilariasis?" Veterinary Parasitology, vol. 133, no. 2-3, pp. 181-189, 2005.

[12] K. Tzanetou, S. Gasteratos, A. Pantazopoulou, C. Gogou, D. Konidaris, and K. Fragia, "Subcutaneous dirofilariasis caused by Dirofilaria repens in Greece: a case report," Journal of Cutaneous Pathology, vol. 36, no. 8, pp. 892-895, 2009.

[13] B. P. Kamalu, "Canine filariasis caused by Dirofilaria repens in southeastern Nigeria," Veterinary Parasitology, vol. 40, no. 3-4, pp. 335-338, 1991.

[14] É. Fok, O. Jacsó, Z. Szebeni et al., "Elimination of Dirofilaria (syn. nochtiella) repens microfilariae in dogs with monthly treatments of moxidectin 2.5\%/imidacloprid $10 \%$ (Advocate®), Bayer) spot-on," Parasitology Research, vol. 106, no. 5, pp. 1141-1149, 2010.

[15] M. A. Peribáez, J. Lucientes, S. Arce, M. Morales, J. A. Castillo, and M. J. Gracia, "Histochemical differentiation of Dirofilaria immitis, Dirofilaria repens and Acanthocheilonema dracunculoides microfilariae by staining with a commercial kit, Leucognost-SPß," Veterinary Parasitology, vol. 102, no. 1-2, pp. 173-175, 2001.

[16] Z. Szénási, A. H. Kovács, S. Pampiglione et al., "Human dirofilariosis in Hungary: an emerging zoonosis in central Europe," Wiener Klinische Wochenschrift, vol. 120, no. 3-4, pp. 96-102, 2008.

[17] O. Ditrich, P. Vítková, F. Stejskal, M. Votruba, and N. Mallátová, "Případ dirofilariózy importované z Řecka (Dirofilariosis imported from Greece-a case report)," in Cestovní medicína: paraziti stále aktuálnějši, pp. 18-22, Česká parazitologická společnost, Prague, Czech Republic, 2009.

[18] F. Ondriska et al., "Human dirofilariosis in the Slovak Republic-a case report," Annals of Agricultural and Environmental Medicine, vol. 17, no. 1, pp. 169-171, 2010.

[19] N. O. F. Jalili, P. Babál, D. Kobzová et al., "Dirofilarióza na Slovensku (Dirofilariosis in Slovakia)," in Cestovní medicína: paraziti stále aktuálnějši, pp. 23-27, Česká parazitologická společnost, Prague, Czech Republic, 2009.

[20] S. Pampiglione and R. Rivasi, "Human dirofilariasis due to Dirofilaria (Nochtiella) repens: an update of world literatura from 1995 to 2000," in Mappe Parassitologiche-Dirofilaria, G. Cringoli, Ed., Naples, Italy, 2007.

[21] I. Kucsera et al., "Human Dirofilaria repens infection in Hungary," in Second European Dirofilaria Days, R. Morchón, F. Simón, J. A. Montoya, and C. Genchi, Eds., pp. 175-184, Salamanca, Spain, 2009. 
[22] L. Venco, "Dirofilaria (Nochtiella) repens infection in dogs and cats," in Mappe Parassitologiche-Dirofilaria, G. Cringoli, Ed., Naples, Italy, 2007.

[23] L. H. Kramer, "Pathogenesis of Dirofilaria spp. infections," in Second European Dirofilaria Days, R. Morchón, F. Simón, J. A. Montoya, and C. Genchi, Eds., pp. 116-123, Salamanca, Spain, 2009.

[24] R. S. V. Dobešová, "Progressive spread of Dirofilaria infections in dogs along rivers in the southeastern Czech Republic," in Secon European Dirofilaria Days, R. Morchón, F. Simón, J. A. Montoya, and C. Genchi, Eds., p. 190, Salamanca, Spain, 2009. 

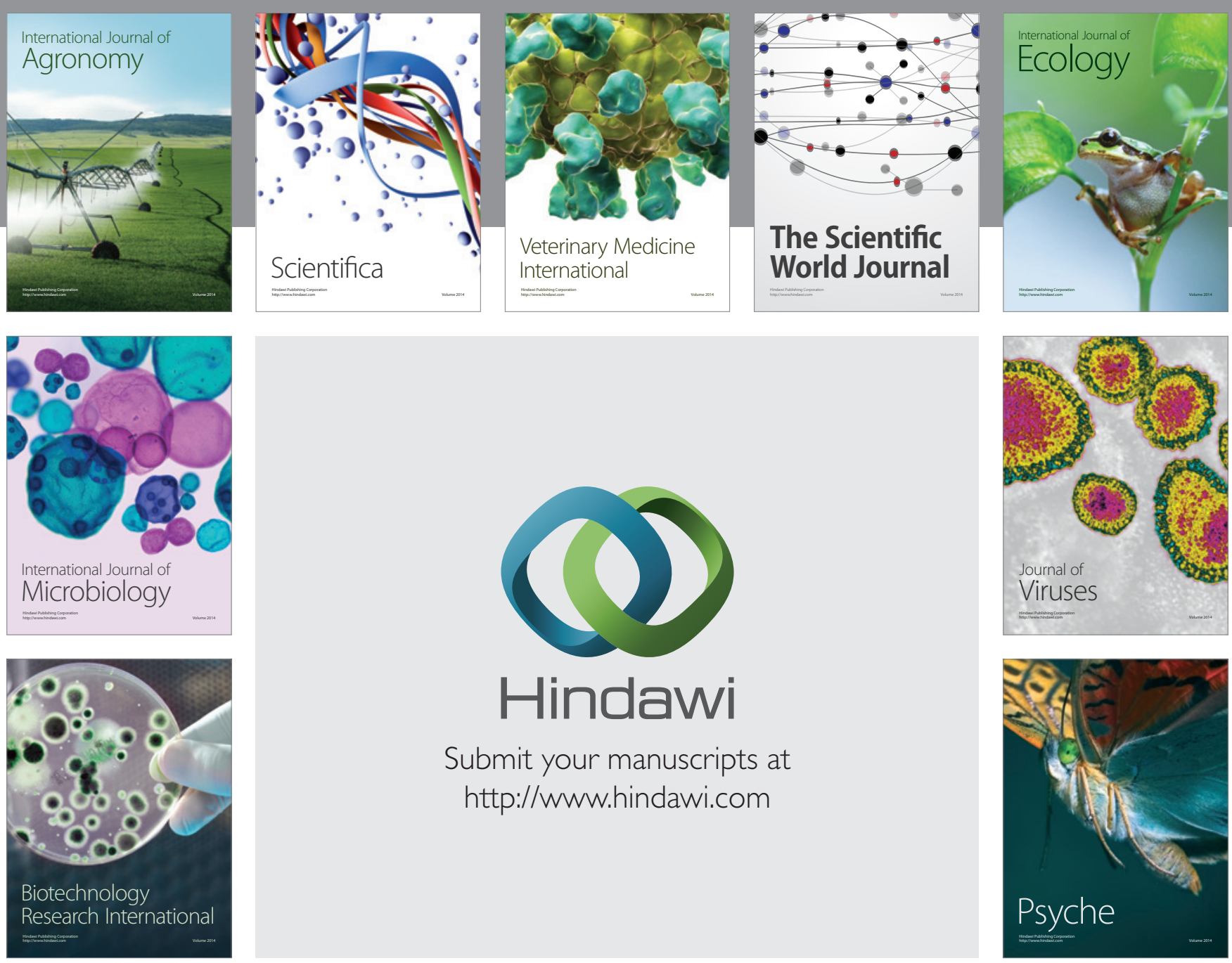

Submit your manuscripts at

http://www.hindawi.com
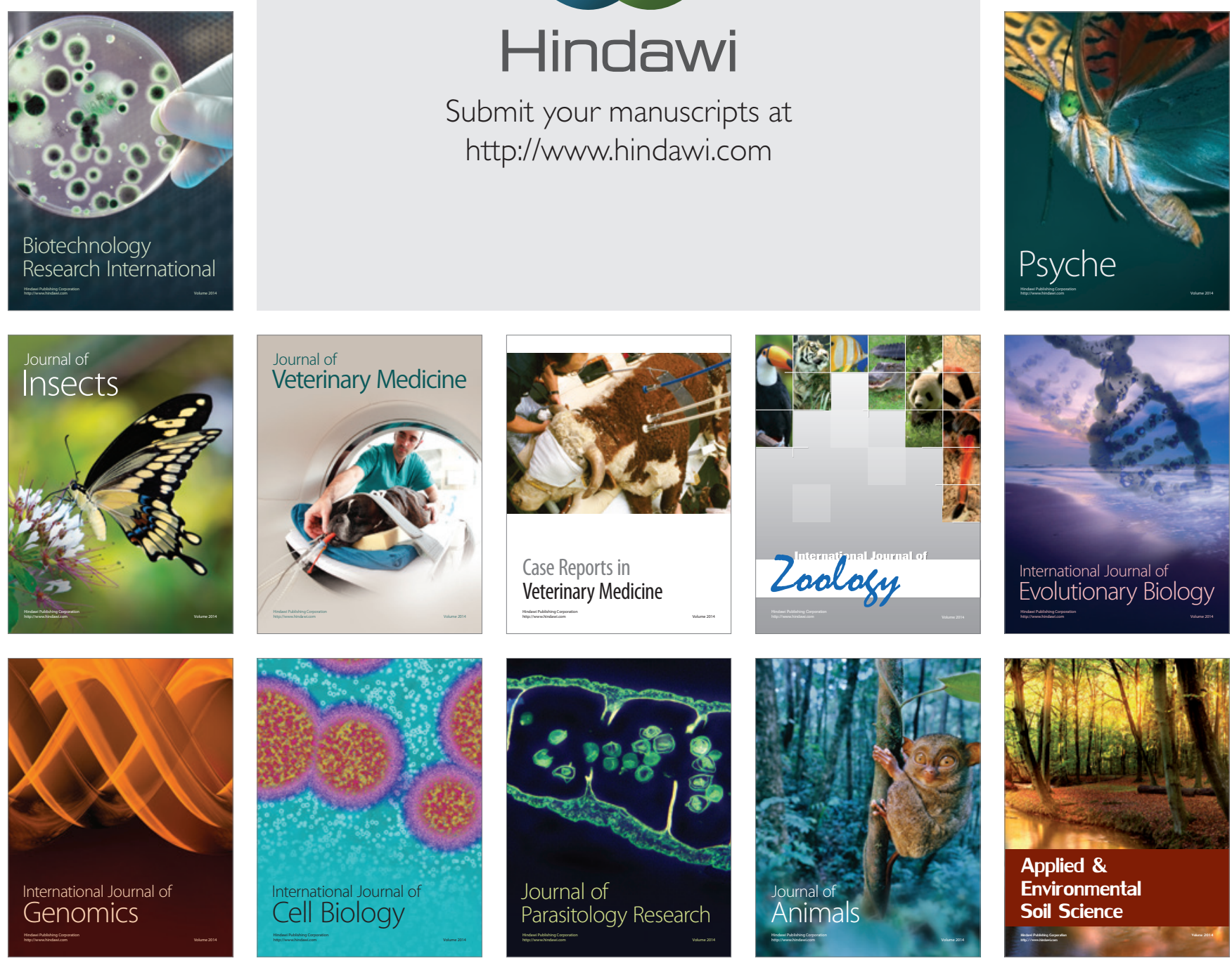